\title{
The Realm of Applied Microbiology, Biotechnology and Genetic Engineering through the Millennia: from Prehistoric Era to Modern Era
}

\section{Behzadi P* and Behzadi E}

Department of Microbiology, College of Basic Sciences, Islamic Azad University, Tehran, Iran

*Corresponding author: Behzadi $\mathrm{P}, \mathrm{PhD}$ in Molecular Biology, Islamic Azad University, Tehran, Iran, Tel: +98-912-4799734; Email: behzadipayam@yahoo.com; p.behzadi@qodsiau.ac.ir

\section{Editorial}

Volume 1 Issue 1

Received Date: April 23, 2016

Published Date: May 02, 2016

DOI: $10.23880 /$ oajmb-16000101

\section{Abstract}

There are some biological sciences which are essential for human being's life. Among an abundance of sciences, applied microbiology, biotechnology and genetic engineering play a key role in our lives. All of these science branches support and guarantee the life continuity and health of human being on the earth. Although the terms of applied microbiology, biotechnology and genetic engineering are novel and new, the sciences are prehistoric in practice. Through the several millennia, the human populations in different regions around the world such as the north part of the Persian Gulf, the Caspian Sea areas, Mesopotamia, etc. have recognized fabulous and incredible biological tools like Saccharomyces cerevisiae which binds the prehistoric era to the modern time. We have no choice to progress and qualify our knowledge to increase the quality of the biological processes.

Keywords: Applied Microbiology; Biotechnology; Genetic engineering; Saccharomyces cerevisiae

\section{Introduction}

Biological techniques such as applied microbiology, biotechnology and genetic engineering are important means that influence the quality of our lives. These terms are heard and seen everywhere; at schools, universities, companies to bars, restaurants, cafeteria etc. The printed and electronic media represent hot discussions regarding the hot terms of applied microbiology, biotechnology and genetic engineering [1].

Indeed, applied microbiology, biotechnology and genetic engineering are super powerful sciences that dominate, control, and improve the human lifestyle in different dimensional pathways. Many people -around the world- are believed that these technologies are novel ones.
Are these scientific branches novel features? Are they originated from the last decades? We can design and propose a mass of questions in association with these terms and technologies.

But the main question is: are these technologies new and novel? Don't they have any historic backgrounds?

The answer is no. The sciences of applied microbiology, biotechnology and genetic engineering have prehistoric backgrounds. The historic and prehistoric evidences show a wide time range for applied microbiology, biotechnology and genetic engineering between 5000 and 50000 years ago in the regions of Black Sea banks, Greece, Caucasus area, Iran plateau [in particular Caspian Sea area and the northern parts of the Persian Gulf], Mesopotamia, Egypt, China and Mediterranean banks. So, the practical applied microbiology, biotechnology and 


\section{Open Access Journal of Microbiology \& Biotechnology}

genetic engineering have been made from the old time, the prehistoric era. But the literature terms are novel [2$4]$.

The term applied microbiology devotes the use of microorganisms for providing a determined product. Bacteria and fungi are the most important biological means in applied microbiology for producing foods, liquors, drinks and antibiotics [2].

The term biotechnology is made of Bio- (life), techno (skill), and-logy (study of ). So, the word biotechnology evokes the use of biological means as a particular technology. The term of biotechnology was coined by the Hungarian agricultural engineer Karl Erkey in 1917; however, the official application (in the format of academic book in Berlin) of this term by K.Erkey is referred to 1919 [1,5-8].

Genetic engineering may be reminding us the discovery of magic molecules of DNA by Freidrich Miescher in 1869. The spatial structure of the molecule was revealed by the famous scientists Watson and Crick in the year of 1953. Interestingly, the term genetic engineering was primarily used by Edward L. Tatum in 1963, but this science is originated from thousands of years ago $[1,8]$.

As mentioned above, applied microbiology, biotechnology and genetic engineering are long-rooted sciences which refer to several millennia ago, the prehistoric era $[2,3,8]$. So we have to remember that, the improvement of human being's life is completely depending on them. The discovery of prehistoric evidences has elucidated us a very huge secret! Our ancestors telling us: USE NATURAL MEANS TO HAVE A QUALIFIED LIFE IN NATURE.

\section{The origin of Applied Microbiology, Biotechnology and Genetic Engineering}

These scientific branches were formed when the human being learned how to cultivate seeds like wheat. According to previous archaeobotanical investigations, applied microbiology, biotechnology and genetic engineering originated $>10000$ years ago; when the human learned how to domesticate the wheat seeds as an important food material [2, 9-11].

The progression of domestication of a diversity of plants like grapevine in different geographical zones in the ancient world, and the lack of hi-tech systems in human life, led to recognition of fermentation. Bread, beer, wine, vinegar, cheese, yogurt etc. are the direct products of applied microbiology and biotechnology. On the other hand, human beings started to learn about grafting plants in ancient era. This knowledge constructed the basis of genetic engineering in new era [2].

So the origination of science branches of applied microbiology, biotechnology and genetic engineering is too old and refers to the ancient world. Of course, it seems incredible! Who could imagine the creation of these sciences in the past?

There are a mass prehistoric and historic evidences regarding seed cultivation in the north part of the Persian Gulf and peripheral zones in Mesopotamia. Moreover, several ancient beer and wine manufacturers have been recognized in the west region of Iran and in particular, the Zagros Mountains. The manufacturing of beer, wine and vinegar is originated from Iran. Different means like Rhytons (Achamaenian animal shaped wine vessels) from archaeological studies support a high level utilization of applied microbiology and biotechnology in Great Persia (Ancient Iran). Besides, many prehistoric and historic evidences relating to fermentation technology have been recognized in different Great Persia States such as Armenia, Arran/Aran Azerbaijan, Georgia, Tajikstan, Turkmenistan, Khwarizm (Uzbekistan), etc. during the governing of Achamaenid dynasty [2,3,12-14].

Saccharomyces cerevisiae: The ancient, classic and modern biological tool: Although there is a wide range of bacterial agents like lactic acid bacteria which are used in food fermentation process, Saccharomyces cerevisiae is a super extraordinary biological tool which binds prehistoric, historic, classical and modern eras to each other. This amazing microorganism encompasses several interesting strains which have specialty in brewery, winemaking, baking, single-cell protein and vaccine productions. The different strains of $S$. cerevisiae have been domesticated throughout several millennia. The incredible genetic characteristics of S.cerevisiae have made this yeast as a magic biological tool that is used in a wide range of applications. As an ancient biological tool, the yeast of S.cerevisiae is applied for brewery, winemaking, beer and bread baking; while this microorganism is a classic and modern tool in single-cell protein and vaccine production. The genomic researches have revealed the unique genetic adaptation of the yeast strains. So, the science branches of applied microbiology, biotechnology and genetic engineering are based on ancient, classic and modern biological tool of S. cerevisiae. Simultaneously, these sciences build the prehistoric, historic and modern principles of human beings' lifestyle $[2-4,12,14,15]$. 


\section{Open Access Journal of Microbiology \& Biotechnology}

\begin{abstract}
Modernization of applied microbiology, biotechnology and genetic engineering by Bioinformatics: What is bioinformatics? What is the relationship of bioinformatics with science branches of applied microbiology, biotechnology and genetic engineering?
\end{abstract}

Bioinformatics is an interdisciplinary science that enables us to illustrate the biological molecules for practical applications. Thus, bioinformatics is able to visualize the molecular biology of the aforementioned sciences throughout the sciences of mathematics and computer. Indeed, computerization of applied microbiology, biotechnology and genetic engineering provide us a bright and brilliant promise. The presence of free databases within internet like National Center for Biotechnology Information (NCBI, http://www.ncbi.nlm.nih.gov/) support us to have a conscious predict and prognosis of genomics, proteomics, metabolomics, etc. regarding a particular microorganism or a collection of microorganisms. Accessory to free GenBank as an important service of NCBI facilitates the process of designing of genomic sequences. Bioinformatics empowers us to increase the quality of biological tools and processes which finally leads to a qualified product $[11,16]$.

Today, by the presence of the hi-tech methodologies we are able to manipulate biological processes and tools for increasing the level of quality of our lives.

\section{Conclusion}

The science branches of applied microbiology, biotechnology and genetic engineering are essentially chains of human being's lifestyle. These sciences are funded when the human populations began how to cultivate seeds and plants and how to domesticate the beneficial microorganisms as important biological tools. The unique genomics of S.cerevisiae has conferred us an excellent opportunity to provide us magic products like bread, beer, wine, vinegar, single-cell proteins, vaccines and other invaluable products. The presence and continuity of human life is completely depending on applied microbiology, biotechnology and genetic engineering. Today, we have to qualify our facilities by novel and modern disciplines and methodologies. There is no doubt about that!

\section{References}

1. Verma AS, Agrahari S, Rastogi S, Singh A (2011) Biotechnology in the realm of history. J Pharm Bioallied Sci 3(3): 321-323.

2. Behzadi P, Behzadi E, Ranjbar R. Microbiology of Fermented Foods. 1st ed. Tehran: Persian Science \& Research Publisher; 2014.

3. Behzadi P, Behzadi E. Modern Industrial Mycology. 1st ed. Tehran: Persian Science \& Research Publisher; 2012.

4. Behzadi P, Behzadi E. Modern Fungal Biology. 1st ed. Tehran: Persian Science \& Research Publisher; 2011.

5. Behzadi P, Behzadi E. Word Mappimg in Biology, Medicine \& Microbiology. 1st ed. Tehran: Persian Science \& Research Publisher; 2012.

6. Bud R (1994) The uses of life: a history of biotechnology. Cambridge University Press.

7. Rao CK (2008) Who coined the terms' biotechnology 'and' genetic engineering', and when? : INDIAN ACAD SCIENCES CV RAMAN AVENUE, SADASHIVANAGAR, PB\# 8005, BANGALORE 560 080, INDIA, p. 1512-3.

8. Niazi G, Riaz-ud-Din S (2006) Biotechnology and genomics in medicine-A review. World J of Med Sci $1(2): 72-81$.

9. Bilgic H, Hakki EE, Pandey A, Khan MK, Akkaya MS (2016) Ancient DNA from 8400 Year-Old Çatalhöyük Wheat: Implications for the Origin of Neolithic Agriculture. PloS one 11(3): e0151974.

10. Kiple KF (2000) The Cambridge World History of Food. Cambridge University Press.

11. Behzadi P, Behzadi E, Ranjbar R (2014) Basic Modern Molecular Biology. 1st ed. Tehran: Persian Science \& Research Publisher.

12. Legras JL, Cornuet JM, Karst F, Merdinoglu D (2007) Bread, beer and wine: Saccharomyces cerevisiae diversity reflects human history. Mol Ecol 16(10): 2091-2102.

13. Behzadi P, Behzadi E (2007) Environmental Microbiology. 1st ed. Tehran: Niktab Publisher.

14. Michel RH, McGovern PE, Badler VR (1993) The First Wine \& Beer 65(8):408A-413A. 


\section{Open Access Journal of Microbiology \& Biotechnology}

15. BEHZADI P, BEHZADI E (2012) Apoptosis - Triggering Effects: UVB-irradiation and Saccharomyces cerevisiae. Maedica (Buchar) 7(4): 315-318.
16. Luscombe NM, Greenbaum D, Gerstein M (2001) What is bioinformatics? An introduction and overview. Yearbook of Medical Informatics. 1: 83-99.

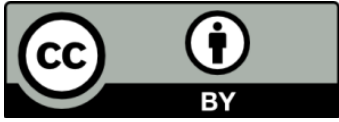

